\title{
Effects of different feed items on the growth and survival of endangered riverine catfish Rita rita (Hamilton)
}

\author{
M.R. Amin, M.F.A. Mollah*, M.R. Ali ${ }^{1}$ and M. Nahiduzzaman
}

Department of Fisheries Biology and Genetics, Bangladesh Agricultural University, Mymensingh-2202,

${ }^{1}$ Bangladesh Water Development Board, Dhaka, Bangladesh

*Corresponding author

\begin{abstract}
The study was conducted to determine a suitable feed for the desirable growth of riverine catfish Rita rita (Hamilton) from January 2006 to December 2006. The experiment had three treatments with three replicates. Nine chambers of the raceway each of size $1.83 \times 1.12 \mathrm{sq}$ meter were used. Local prawn, chicken viscera and commercially available formulated feed (CP) were supplied in treatment $T_{1}, T_{2}$ and $T_{3}$, respectively at the rate of $7 \%$ body weight. Feed was supplied twice in a day in the early morning and in the evening as the fish is nocturnal. The initial average weight of fish was $24.93 \pm 0.05 \mathrm{~g}, 24.99 \pm 0.04 \mathrm{~g}$ and $24.95 \pm 0.04 \mathrm{~g}$ in $\mathrm{T}_{1}, \mathrm{~T}_{2}$ and $\mathrm{T}_{3}$, respectively. The final weight of the fish under three treatments was $425.05 \pm 1.04 \mathrm{~g}, 425.68 \pm 1.05 \mathrm{~g}$ and $177.61 \pm 1.45 \mathrm{~g}$ respectively. The initial length was $8.48 \pm 0.02,8.49 \pm 0.02$ and $8.50 \pm 0.01$ in $T_{1}, T_{2}$ and $T_{3}$, respectively. The final length was $25.22 \pm 0.06 \mathrm{~cm}, 25.21 \pm 0.14 \mathrm{~cm}$ and $14.87 \pm 0.13 \mathrm{~cm}$ in $T_{1}$, $T_{2}$ and $T_{3}$, respectively. The mean final weight and length was significantly $(p<0.05)$ higher in $T_{1}$ and $T_{2}$ compared with $T_{3}$. However, there was no significant difference $(p>0.05)$ between $T_{1}$ and $T_{2}$ in terms of final weight and length was concerned. Better growth performances, however, were observed in $\mathrm{T}_{2}$ and $\mathrm{T}_{1}$, where prawn and chicken viscera were supplied as feed respectively. Lowest growth performance was observed in $\mathrm{T}_{3}$ where formulated feed (CP feed) was supplied.
\end{abstract}

Key Words: Riverine Catfish, Feed, Growth, SGR, Survival.

\section{Introduction}

Food is the main source of energy and plays an important role in determining the population levels, rate of growth and condition of fishes. It is very important to know the food and feeding habit of a particular fish species, especially the fish which is going to domesticated in the aquaculture system. $R$. rita is a riverine catfish which is critically engendered now (IUCN, 2000). The catfish $R$. rita is known to be highly predaceous and carnivorous in habit (Devi et al.,1992). Earlier attempts on the food and feeding habit of some freshwater catfishes have been undertaken by Majumder (1969), Bhatt (1970 \&1971), Majumder \& Das (1979), Qayyum \& Qasim (1964), Ahmed et al. (1990), Anwar \& Siddiqui(1992). Little information also can be found regarding high protein added feed which has been used for the culture of fresh water catfishes (David, 1963 \& Sarder, 1992). Khan (1934) and Das \& Moitra (1956) published brief accounts of the food and feeding habits of $R$. rita. However, no studies have yet been done about the culture of $R$. rita and its feed which can ensure the better growth performances under aquaculture. Therefore the present investigation has been undertaken to determine a suitable feed for the culture of riverine catfish $R$. rita.

\section{Materials and method}

\section{Experiment site}

The experiment was carried out for a period of one year from January to December 2006 in raceway located alongside Faculty of Fisheries, Bangladesh Agricultural University, Mymensingh.

\section{Preparation of chamber in raceway}

The experiment was designed with three treatments designated as $T_{1}, T_{2}$ and $T_{3}$, with three replicates i.e. a total of 9 (nine) chambers were utilized for the experiment. The area of each chamber was $1.83 \times 1.12$ sq. meter. Each chamber was separated from each other with the nylon net attached by means of a wooden frame. Depth of water in the raceway was maintained at 1.2 meter which means all nine chambers of three treatments had equal depth of 1.2 meter. One third water was changed every two days after and the entire water was completely altered fortnightly.

\section{Diet formulation and application}

Chicken viscera, local prawn and commercially available formulated feed (CP) were supplied twice in a day in $T_{1}, T_{2}$ and $T_{3}$, respectively at the rate of $7 \%$ body weight. Chicken viscera and local 
prawn were collected from neighboring market and chopped before applied. Percentage of protein in chicken viscera, local prawn and formulated feeds were 47.58, 45.75 and 43.50, respectively (Table-1). As the fish is nocturnal half of the feed was supplied early in the morning and remaining half was supplied in the evening. Feed was supplied near the shelter made for the fish.

Table 1: Proximate composition of the ingredients (\% dry matter basis) used in preparation of the diet for monoculture of Rita rita in the raceway

\begin{tabular}{|l|l|c|c|c|c|}
\hline Treatment & Feed used & $\begin{array}{c}\text { Protein } \\
(\%)\end{array}$ & $\begin{array}{c}\text { Lipid } \\
(\%)\end{array}$ & $\begin{array}{c}\text { Ash } \\
(\%)\end{array}$ & $\begin{array}{c}\text { Dry } \\
\text { matter (\%) }\end{array}$ \\
\hline $\mathrm{T}_{1}$ & $\begin{array}{l}\text { Chicken } \\
\text { viscera }\end{array}$ & 47.58 & 15.78 & 6.74 & 16.71 \\
\hline $\mathrm{T}_{2}$ & Prawn & 45.75 & 13.45 & 5.65 & 13.80 \\
\hline $\mathrm{T}_{3}$ & $\begin{array}{l}\text { Formulated } \\
\text { feed }\end{array}$ & 43.50 & 6.45 & 9.50 & 21.75 \\
\hline
\end{tabular}

\section{Source of juveniles and rearing system}

Seventy juveniles of $R$. rita were collected from the river old Brahmaputra in the month of April 2005. Then they were maintained in the cistern with water flow for about one month to acclimatize when they were fed with earthworms and tubificid worms. After acclimatization, 54 juveniles of 65 survivors were used for the experiment. Only one stocking density (6 juveniles/chamber) was assigned to the treatments. Juveniles of similar weight were used to stock in all the chambers. The mean initial weight of the juvenile, however, was $24.93 \pm 0.05 \mathrm{~g}, 24.99 \pm 0.04 \mathrm{~g}$ and $24.95 \pm 0.04 \mathrm{~g}$ in $T_{1}, T_{2}$ and $T_{3}$, respectively.

\section{Sampling}

Monthly sampling was done and adjusted the required amount of feed for the fishes. After each sampling, length $(\mathrm{cm})$ weight $(\mathrm{g})$, survival rate, specific growth rate (SGR), and net fish yield were also calculated. The survival rate, SGR, and yield in different treatments were measured by using following formulae.

Survival $(\mathrm{S} \%)=\left(\mathrm{N}_{\mathrm{e}} / \mathrm{N}_{\mathrm{i}}\right) \times 100$

Where, $\mathrm{N}_{\mathrm{i}}=$ Number of fish stocked and

$\mathrm{N}_{\mathrm{e}}=$ Number of fish at harvest.

SGR $=[$ Ln (final weight)-Ln (initial weight) $\times 100] /$ culture period (days).

Net yield $=\left(W_{e}-W_{i}\right) / A$

Where, $W_{\mathrm{e}}=$ Fish at harvest $(\mathrm{kg})$,

$\mathrm{W}_{\mathrm{i}}=$ Fish at stock $(\mathrm{kg})$ and $\mathrm{A}=$ Area
Feed conversion ratio $(\mathrm{FCR})=$ Weight gain $/ \mathrm{By}$ using per $\mathrm{kg}$ feed

\section{Analytical methods and statistical analysis}

The proximate composition of the diet ingredients was analyzed according to AOAC (1990). Growth (length and weight) data were analyzed using one-way analysis of variance (ANOVA) followed by Duncan's multiple range test (DMRT) at the $5 \%$ level of significance to detect differences among treatment means. All statistical analyses were performed by SPSS (Windows version 11.5). Standard error ( \pm SE) of treatment means was calculated from the residual means square in the ANOVA.

\section{Results and Discussion}

The growth performance values in terms of weight gain (g), specific growth rate (SGR, \% day), food conversion ratio (FCR), survival (\%) and production of Rita rita in different treatments are shown in Table 2. The body weight increased with the progress of study period. The significantly $(p<0.05)$ highest growth (in weight) was observed in $\mathrm{T}_{1} \quad(425.68 \pm 1.13 \mathrm{~g})$ followed by $\mathrm{T}_{2}$ $(425.05 \pm 1.03 \mathrm{~g})$ and the lowest growth was observed in $T_{3}(177.61 \pm 1.45 \mathrm{~g})$ which is shown in the Table 2.

Table 2: Growth and survival of riverine catfish Rita rita fed with different feeds.

\begin{tabular}{|l|l|l|l|}
\hline \multicolumn{1}{|c|}{ Parameters } & \multicolumn{1}{c|}{$\mathbf{T}_{1}$} & \multicolumn{1}{c|}{$\mathbf{T}_{2}$} & \multicolumn{1}{c|}{$\mathbf{T}_{3}$} \\
\hline Initial weight (g) & $24.93 \pm 0.05^{\mathrm{a}}$ & $24.99 \pm 0.04^{\mathrm{a}}$ & $24.95 \pm 0.04^{\mathrm{b}}$ \\
\hline Final weight (g) & $425.05 \pm 1.04^{\mathrm{a}}$ & $425.68 \pm 1.13^{\mathrm{a}}$ & $177.61 \pm 1.5^{\mathrm{b}}$ \\
\hline Weight gain (g) & $400.12 \pm 0.67^{\mathrm{a}}$ & $400.69 \pm 1.05^{\mathrm{a}}$ & $152.66 \pm 0.66^{\mathrm{b}}$ \\
\hline$\%$ Weight gain & 1604.97 & 1603.40 & 611.86 \\
\hline Initial length(cm) & $8.48 \pm 0.02^{\mathrm{a}}$ & $8.49 \pm 0.02^{\mathrm{a}}$ & $8.50 \pm 0.01^{\mathrm{b}}$ \\
\hline Final length(cm) & $25.21 \pm 0.14^{\mathrm{a}}$ & $25.22 \pm 0.06^{\mathrm{a}}$ & $14.87 \pm 0.13^{\mathrm{b}}$ \\
\hline Length gain(cm) & $16.73 \pm 0.82^{\mathrm{a}}$ & $16.73 \pm 0.07^{\mathrm{a}}$ & $6.37 \pm 0.64^{\mathrm{b}}$ \\
\hline$\%$ Length gain & $197.29^{\mathrm{a}}$ & $197.05^{\mathrm{a}}$ & $72.39^{\mathrm{b}}$ \\
\hline Survival rate (\%) & 100 & 100 & 88.8 \\
\hline ADG & $1.10^{\mathrm{a}}$ & $1.10^{\mathrm{a}}$ & $0.42^{\mathrm{b}}$ \\
\hline SGR (\%) & $109.62^{\mathrm{a}}$ & $109.78^{\mathrm{a}}$ & $41.82^{\mathrm{b}}$ \\
\hline $\begin{array}{l}\text { Feed conversion } \\
\text { ration (FCR) }\end{array}$ & $0.40^{\mathrm{a}}$ & $0.40^{\mathrm{a}}$ & $0.15^{\mathrm{b}}$ \\
\hline Yield (kg/m $\left.{ }^{2}\right)$ & $1.17^{\mathrm{a}}$ & $1.17^{\mathrm{a}}$ & $0.45^{\mathrm{b}}$ \\
\hline
\end{tabular}

All values were reported as mean standard error ( \pm S.E.) of the mean Figures in the same row having the same superscripts are not significantly different $(p>0.05)$ and having different superscripts are significantly different $(p<0.05)$.

The body length also increased during the study period. The significantly $(p<0.05)$ highest growth (in length) was observed in $\mathrm{T}_{2}(25.22 \pm 0.06 \mathrm{~cm})$ followed by $T_{1}(25.21 \pm 0.14 \mathrm{~cm})$ and lowest growth $(14.87 \pm 0.13 \mathrm{~cm})$ was observed in $T_{3}$ which is shown in Table 2. 
However, the mean final weight $(\mathrm{g})$ and length $(\mathrm{cm})$ was significantly $(p<0.05)$ higher in $\mathrm{T}_{1}$ and $\mathrm{T}_{2}$ compared with $T_{3}$. But there was no significant difference $(p>0.05)$ between $T_{1}$ and $T_{2}$ in terms of final weight and length was concerned. Likewise, average daily growth (ADG), specific growth rate (SGR \%), feed conversion ration (FCR) and yield $\left(\mathrm{kg} / \mathrm{m}^{2}\right)$ showed significantly higher in $\mathrm{T} 1$ and $\mathrm{T}_{2}$ compared with $\mathrm{T}_{3}$ (Table 2). However, the survival rate was $100 \%$ in $T_{1}$ and $T_{2}$ and $88.8 \%$ in case of $\mathrm{T}_{3}$ which was significantly lower $(p<0.05)$.

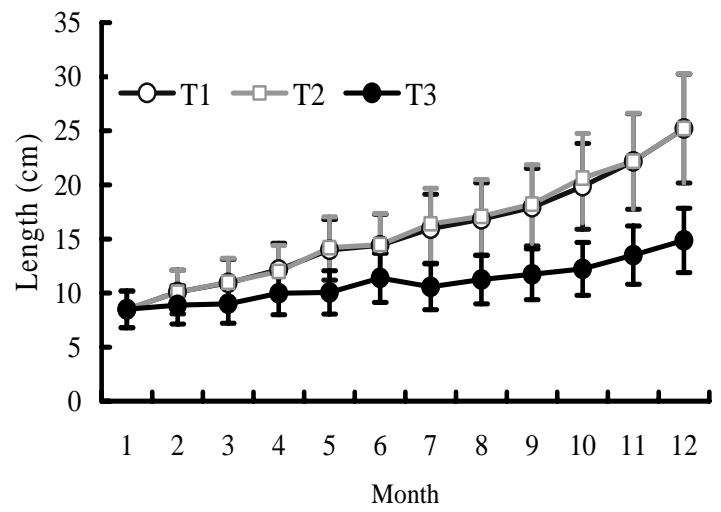

Fig. 1: Monthly length $(\mathrm{cm})$ increment of Rita rita when reared using chicken viscera $\left(T_{1}\right)$ local prawn $\left(T_{2}\right)$ and commercial feed $\left(T_{3}\right)$

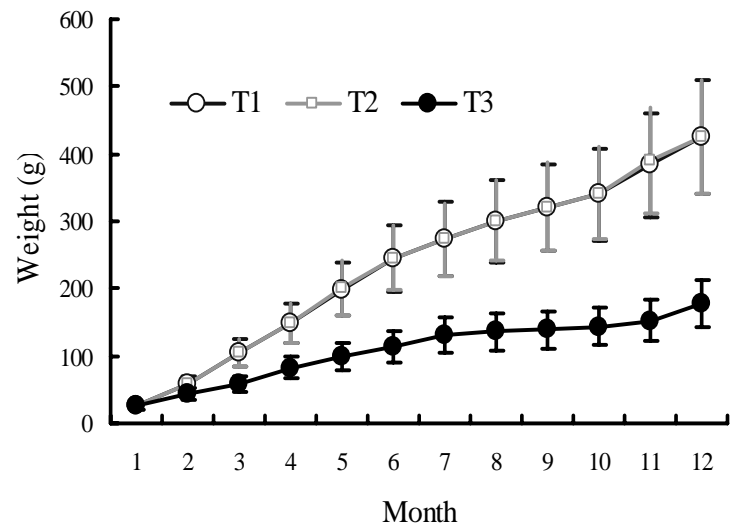

Fig 2. Monthly weight $(\mathrm{g})$ increment of Rita rita when reared using chicken viscera $\left(T_{1}\right)$ local prawn $\left(T_{2}\right)$ and commercial feed $\left(T_{3}\right)$

R. rita is a riverine catfish found all over Bangladesh. Its abundance has been reported to be declining day by day for various reasons applicable to many other species, inhabiting Bangladesh. One of the probable mitigating measures that can be taken against the extinction of this species is to domesticate under aquaculture. Aquaculture of this critically endangered fish can be an in situ strategy for its conservation. Commercial aquaculture might be possible, if farming technique is available and the nature of supplementary is determined under aquaculture. The farming of this fish may be profitable as the fish are comparatively high price in the market. In the present study, it has been observed that though the protein percentages were more or less same (Table-1) in all the treatments but better growth performances have been found in case of prawn and chicken viscera which were supplied as feed. But lower growth performance has been found in case of $\mathrm{T}_{3}$ (Fig. 1 $\& 2$ ) where formulated feed was used.

It was observed that the fish easily took prawn and chicken viscera as feed but it was not happened when formulated feed was provided. It might be due to the fact that the fish are used to inhabit around the rocky areas of the river basin and not habituated on traditional supplementary feed as widely used in polyculture system in Bangladesh. The fish have also been reported to be dependent on the fauna of their surroundings, namely insects' larvae, insect nymphs, crustaceans, gastropods, lamellibranchiates and fish (Devi et al.,1992). Khan (1934) also reported that $R$. rita fed mostly on insects, their larvae and prey fish. Rahman et al. (1997) conducted an experiment on effects of different feeds on the growth of Clarias batrachus and found best result fed using $40 \%$ protein containing feed. Similar results also obtained by Henken et al. (1986) in case of Clarias gariepinus. Nahar et al. (2000) and Winfree \& Stickney (1984) found to be the best results using $58 \%$ protein containing feed. The findings of the present experiment are more or less similar to those mentioned above. Finally it might be concluded that among three feeds 'chicken viscera' is available and also cheap in comparison to other experimented feeds while 'local prawn' is available but comparatively costly to be used as feed. So prawn will not be economically viable for the culture of riverine catfish $R$. rita and growth performance with the formulated feed is not satisfactory. Therefore chicken viscera can be recommended for culture of riverine catfish $R$. rita.

\section{References}

Ahmad, M.U., Khumar, F., Anwar, S. \& Siddiqui, M.S. 1990. Preliminary observations on the growth and food of the murrel Channa marulius (Bloch) of the River Kali in north India. J. Freshwater Biol., 2(1): 47-50. 
Anwar, S. \& Siddqui, M.S. 1992. Observation on the predation by Mystus seenghala (Sykes) and Wallago attu (Bloch \& Schneider) of the river Kali in North India. J. Environ. Biol., 33(1): 47-54.

AOAC (Association of Official Analytical Chemists) (1990) In: Official Methods of Analysis, 15th edn, (ed. by $\mathrm{H}$. Kenneth), AOAC, Arlington, VA, USA, 1298pp.

Bhatt, V.S. 1970. Studies on the biology of some freshwater fishes. Part IV. Mystus seenghala (Sykes). J. Bombay nat. Hist. Soc., 67: 194-211.

Bhatt, V.S. 1971. Studies on the biology of some freshwater fishes. Part V. Mystus vittatus (Bloch) J. Bombay nat. Hist. Soc., 68(3): 556-572.

Das, S.M. \& Moitra, S.K. 1956. Studies on the food of common fishes of Uttar Pradesh. Part IV-on the types of fish food and the variations in the relative length of the alimentary canal. Proc. Nat. Acad. Sci., India (B), 26(4): 213-223.

David, A. 1963. Fisheries biology of the schilbeid catfish, Pangasius pangasius (Ham.) and its utility and propagation in culture ponds. Indian J. Fish., 10(2A): 521-600.

Devi, N.T., Anwar, S. \& Siddiqui, M.S. 1992. On the food of the catfish Rita rita ( Ham.) of the river Yamuna. J. Inland Fish. Soc., 24(1): 34-39.

Henken, A.M., Machiels, M.A.M., Deeker, W. \& Hogendoorn, H. 1986. The effects of dietary protein and energy content on growth rate and feed utilization of the African catfish, Clarias gariepinus (Burchell 1922). Aquaculture, 58: 55-74.
IUCN, Bangladesh 2000. Red book of threatened fishes of Bangladesh. Islam, M.A., Ameen, M., and Nishat, A. (eds.). The World Conservation Union, Dhaka, Bangladesh. $160 \mathrm{p}$

Khan, H. 1934. Habits and habitats of the food fishes of the Punjab. J. Bombay nat. Hist. Soc., 37: 657-662.

Majumder, P. 1969. Food of the catfish, Tachysurus thalassinus (Ruppell). Indian J. Fish., 16: 161-169.

Majumder, P. \& Das, S.S. 1997. Studies on food and feeding habits of catfish, Tachysurus tenuispinis (Day). Indian J. Fish., 26:(1\& 2): 115-124.

Nahar, Z., Shah, A.K.M.A., Bhanadari, R.K., Ali, M.H. \& Dewan, S. 2000. Effect of different feeds on growth, survival and production of African catfish (Clarias gariepinus). Bangladesh J. Fish. Res., 4(2):121-125.

Qayyum, A \& Qasim, S.Z. 1964. Studies on the biology of some freshwater fishes. Part 1. Ophicephalus punctatus Bloch. J. Bombay nat. Hist. Soc.61:74-78.

Rahman, M.A., Badhra, A., Begum, N. \& Hossain, M.G. 1997. Effects of some selective supplemental feeds on the survival and growth of catfish (Clarias batrachus Lin.) fry. Bangladesh J. Fish. Res., 1(2):55-58.

Sarder, M.R.I. 1992. Culture feasibility of Pangas, Pangasius pangasius (Ham.) in floating net cages. MS Thesis, Department of Fisheries Biology and Limnology, Bangladesh Agricultural University, Mymensingh. p. 99.

Winfree, R.A. \& Stickney, R.R. 1984. Formulation and processing of hatchery diets for channel catfish. Aquaculture, 41: 311-323. 